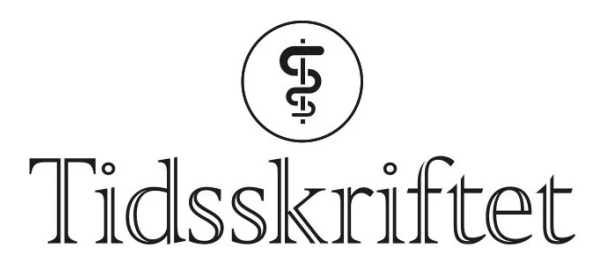

DEN NORSKE LEGEFORENING

\title{
Kvinners helse i hele verden
}

\author{
ANMELDELSER
}

JOHANNE SUNDBY

Seksjon for internasjonal helse Universitetet i Oslo

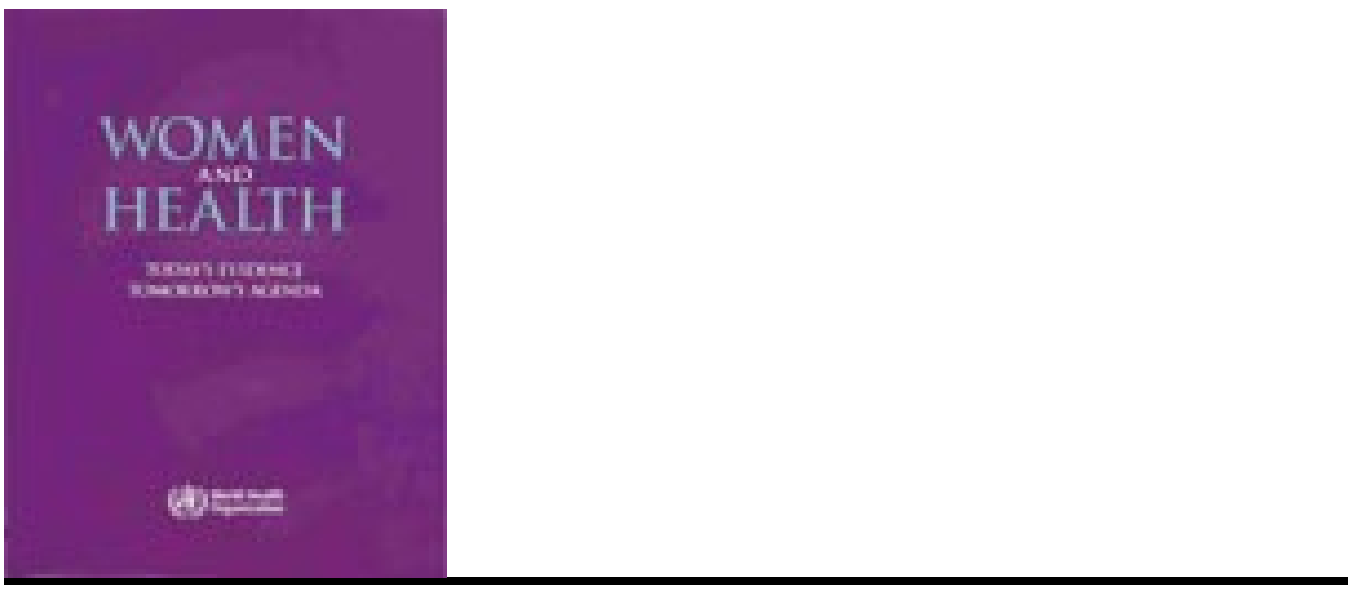

helseorganisasjon, Verdens

Women and health

Today's evidence, tomorrow's agenda. 107 s, tab, ill. Genève: WHO, 2009. Pris CHF 30

ISBN 978-92-4-156385-7

En liten, rødfiolett bok uten forsidebilde, ikke en gang av en lykkelig gravid, hvit kvinne i Vesten, men med en agenda om endring for verdens kvinner. Teksten er vel typisk for WHO: kort, uten altfor mange eksempler, men med et rammeverk som forklarer hvordan boken er bygd opp. Den er global i sitt utsyn og inneholder mange tabeller og mye statistikk. Imidlertid kunne den med fordel hatt flere ekte bilder. Samtidig forklarer skribentene at det faktisk er et stort kunnskapshull her: Vi vet for lite om kvinners helse. Vi har for lite data.

Som norsk lege, som for ti år siden var leder for en gruppe som leverte en tilsvarende oversikt til det norske samfunnet (1) , er nok mine kommentarer ganske farget. Fordi boken er global blir den kanskje for uspesifikk. Det er store ulikheter mellom kvinners helse og skjebne i ulike deler av verden, og kvinners helse eller sykdom er svært nær knyttet til den 
største helseulikhetsdeterminanten: fattigdom. Istedenfor å utforske dette i større detalj, og la det være rammen, ved å gi oss tydelige eksempler på hvordan dette også spesielt forklarer hvorfor noen av verdens kvinner kommer så utrolig dårlig ut (for eksempel mødredødelighet, der 99\% rammer kvinner i de fattige landene), legger de et livsløpsperspektiv på presentasjonen. Jeg skjønner det, for kvinners helse skal vokse ut over ideen om at det bare dreier seg om svangerskap og fødsel. Men noen steder blir faktisk denne måten å dele det inn på, litt tam: I kapitlene om barne- og ungdomshelse finner jeg ikke veldig mye spesifikt for kvinner. For eksempel er anoreksi og bulimi samt selvskading nesten ikke omtalt i det hele tatt som et ernærings- eller mentalhelseproblem hos unge jenter. På den annen side er boken spekket med data om ulikhetene, slik at det ligger der, og det er ubehagelig lesning.

Typisk for publikasjoner fra WHO, så er det politiske begrensninger for hva man kan skrive om. Det som ofte er et dilemma for WHO, er å skrive om abort. Bidragsyterne presenterer ikke tilgang på aborttjenester i ulike land som en helserett, ei heller for krigsvoldtatte kvinner (sivile med skader, påført i krig, skal ha adekvat nødhjelp). Farlige, illegale aborter er nevnt, men for de av oss som har kjempet for kvinners rett til reproduktiv helse, er abortproblematikken ikke bra nok tatt opp her.

På den annen side er boken spekket med data, mest på befolkningsnivå. Jeg mener at en bok om kvinners helse ikke bør falle i den fellen at de publiserer eller presenterer "percentage of people». I en bok om kjønn og helse er det enten sammenlikninger mellom menn og kvinner som gjelder, eller kjønnssegregerte analyser (side 54).

Trenger man data og statistikk, er denne boken bra å ha. Man blir også sterkt oppfordret til å øke forskningen på kvinners helse. Hvis man skal gjøre prinsippvalg om kvinner og helse, mener jeg at den faktisk er for global. Personlig liker jeg ikke aldersfaseoppdelingen fordi jeg faktisk ser mitt og andre kvinners liv som en helhet. Men en eller annen organisering bør man jo ha. Hvis man bruker mannen som norm, er kvinners helse lettere å forstå, men kanskje man da glemmer noen ting. Etter vår norske hjemlige debatt nylig, om kjønn, biologi og sosial konstruksjon, synes jeg boken fra WHO blir litt tynn og litt lite spenstig. Kanskje vi i Norge tar mye av dette for gitt? Eller har hørt det før? Et hovedspørsmål vil jo alltid være om det går an å bedre kvinners helse uten fundamentalt å endre på kvinners livsvilkår. Bidragsyterne sier noe om dette, men de tar ikke spranget helt ut, selv om de henvender seg til fremtiden. På et globalt nivå er det likevel en milepæl at boken har kommet. Det var jammen på tide!

LITTERATUR

1. Norges offentlige utredninger. Kvinners helse i Norge. NOU 1999:13.

Publisert: 7. januar 2011. Tidsskr Nor Legeforen. DOI: 10.4045/tidsskr.10.1125

(C) Tidsskrift for Den norske legeforening 2023. Lastet ned fra tidsskriftet.no 26. april 2023. 